\title{
Role of trimetazidine in carbon tetrachloride induced liver damage in rats
}

\author{
Vijay H. Mate*, Vijaya A. Pandit, Dileep B. Wani, Priti P. Dhande
}

Department of Pharmacology, Bharati Vidyapeeth (DU)

Medical College, Pune-411030, Maharashtra, India

Received: 9 December 2013 Accepted: 31 December 2013

*Correspondence to:

Dr. Vijay H. Mate,

Email: vijayhmate@gmail.com

(C) 2014 Mate VH et al. This is an open-access article distributed under the terms of the Creative Commons Attribution Non-Commercial License, which permits unrestricted non-commercial use, distribution, and reproduction in any medium, provided the original work is properly cited.

\begin{abstract}
Background: Hepatotoxicity by chemicals and drugs is a common clinical problem. Presently very few drugs are showing effectiveness in prevention and treatment of hepatic damage. So in this study, we evaluated the role of trimetazidine in carbon tetrachloride $\left(\mathrm{CCl}_{4}\right)$ induced liver damage in rats. Objective of current study is to evaluate effects of prophylactic trimetazidine against carbon tetrachloride induced liver damage in rats.
\end{abstract}

Methods: Liver damage was induced in 30 albino rats by $\mathrm{CCl}_{4}(0.5 \mathrm{ml} / \mathrm{kg}$, i.p. $)$ once daily for 7 days. Extent of damage was studied by assessing biochemical parameters (SGOT, SGPT, ALP, proteins and bilirubin). These biochemical observations were supplemented by pentobarbitone Sleeping Time and Histological Examination of liver. The effect of co-administration of trimetazidine (doses 5 and $10 \mathrm{mg} / \mathrm{kg} \mathrm{p}$. o.) on the above parameters was investigated. Liv. $52^{\circledR}$ was used as Positive Control. Data was analyzed by one way ANOVA, followed by Dunnett's test.

Results: Trimetazidine significantly prevented $\mathrm{CCl}_{4}$ induced elevation of serum SGOT, SGPT, ALP and bilirubin (total and direct), and reduction in protein level. Pentobarbitone sleeping time and histological examination of the liver showed consistent results. The results were comparable to that of Liv. $52^{\circledR}$.

Conclusions: Trimetazidine, when administered prophylactically, shows hepatoprotective effect against $\mathrm{CCl}_{4}$ induced liver damage.

Keywords: Trimetazidine, Hepatoprotective, Prophylactic

\section{INTRODUCTION}

Hepatotoxicity induced by chemicals and drugs is a common problem encountered in the clinical practice. Liver injury produced by drugs is an iatrogenic disorder and its incidence is increasing in recent times. It has been estimated that approximately $2 \%$ of jaundiced patients admitted to general hospitals have drug induced liver disease $^{1}$ while in geriatric population this figure may be as high as $20 \%{ }^{2}$ Drug induced liver injury can mimic almost every naturally occurring liver disease in man. The susceptibility of the liver to damage is a consequence of its primary role in drug metabolism.

The vast array of chemicals to which we are exposed is expanding and the number of implicated agents continues to increase; hence awareness of chemical as well as drug induced liver disease and its prevention is important to plan the strategy for prevention and treatment of liver damage by xenobiotics.

There are many compounds both organic and inorganic capable of causing liver injury, when gain access to the body. Examples of some commonly used chemicals having propensity for producing hepatic damage are carbon tetrachloride $\left(\mathrm{CCl}_{4}\right)$, trichloroethylene, yellow phosphorus etc. Pharmacological agents commonly used in medical therapy like paracetamol, isoniazid, chlorpromazine, halothane, methyldopa etc. also produce liver damage. ${ }^{3}$ Most of these agents cause hepatotoxicity as a side effect when employed in therapeutic doses. 
At present, there are very few drugs like N-acetyl-Lcysteine (NAC), ${ }^{4}$ S-adenosyl methionine, ${ }^{5}$ number of antioxidants (including Vitamin E), ${ }^{6}$ which have been conclusively shown to be effective in prevention and treatment of liver damage. Various indigenous agents and compound formulations have been studied for their hepatoprotective activity. Drugs which are available from herbal medicines lack in purity and usually are combination of multiple herbs.

Trimetazidine (1-[2,3,4-trimethoxy-benzyl] piperazine hydrochloride $)^{7}$ (TMZ) is a drug used in angina pectoris which acts by nonhaemodynamic mechanisms. ${ }^{8}$ In patients not adequately controlled by long-acting nitrates or beta blockers or calcium channel blockers, addition of TMZ has shown to further reduce anginal attacks and increase exercise tolerance. Though the exact mechanism of action is not known, postulated mechanisms are:

a) Inhibition of mitochondrial long chain 3-ketoacyl-coAthiolase (LC 3KAT), a key enzyme in fatty acid oxidation-thereby reducing fatty acid metabolism and increasing glucose metabolism. Fatty acid oxidation requires more oxygen than glucose oxidation and so shift to glucose metabolism would reduce oxygen demand.

b) Protecting against $\mathrm{O}^{\bullet}$ free radical induced membrane damage and reduction of intracellular acidosis and $\mathrm{Na}^{+}$, $\mathrm{Ca}^{++}$accumulation during ischaemia.

TMZ has been shown to inhibit fatty acid oxidation and thereby reducing biosynthesis of fats. Hence this study was planned to explore the effect of prophylactic administration of $\mathrm{TMZ}$ in $\mathrm{CCl}_{4}$ induced liver damage in albino rats.

\section{METHODS}

The study was done after obtaining approval of IAEC (Approval Letter No. IAEC /BVDUMC/07/2009-2010 dated 2/9/2009) and in accordance with the guidelines provided by Committee for the Purpose of Control and Supervision of Experiments on Animals (CPCSEA).

\section{Animals}

Study was conducted on 30 Albino Wistar rats of either sex weighing150-200 gms procured from the Central Animal House of Bharati Vidyapeeth Deemed University Medical College, Pune. They were housed under standard conditions of temperature $\left(22 \pm 2^{\circ} \mathrm{C}\right)$, relative humidity $(55 \pm 5 \%)$ and light (12 h light/dark cycles). They were fed with standard pellet diet and aquaguard water $a d$ libitum. They were maintained in clean, sterile polypropylene cages.

\section{Drugs and Chemicals}

1) Trimetazidine (TMZ): It is available as Trivedon-20 tablets manufactured by Cipla Ltd, Solan, H.P., India which contains trimetazidine Dihydrochloride 20 $\mathrm{mg} /$ tablet. It is the drug used to evaluate its hepatoprotective effect. It is water soluble drug. The minimum and maximum single daily dose of trimetazidine used in human was extrapolated to rats by using the dose conversion table based on body surface area. ${ }^{9}$ Minimum and maximum doses were labeled as $\mathrm{TMZ}_{1}(5 \mathrm{mg} / \mathrm{kg})$ and $\mathrm{TMZ}_{2}(10 \mathrm{mg} / \mathrm{kg})$ respectively and were administered orally.

2) Carbon tetrachloride $\left(\mathrm{CCl}_{4}\right)$ : It was obtained from central Drug House Private Ltd, New Delhi (Laboratory Reagent Grade, Mol.Wt.153.82), chemical used to induce liver damage. $\mathrm{CCl}_{4}$ was used in the dose of $0.5 \mathrm{ml} / \mathrm{kg} / \mathrm{d}$ i.p. for 7 days. ${ }^{10}$

3) Liv. $52^{\circledR}$ : Syrup Liv. $52^{\circledR}$ was obtained from The Himalaya Drug Company, Solan, H.P., India. It is polyherbal drug effective against many liver disorders. ${ }^{11}$ It was used as positive control and given in the dose of $1 \mathrm{ml} / \mathrm{kg}$ orally. ${ }^{12,13}$

4) Pentobarbitone Sodium: pentobarbitone sodium from Loba Cheimie Industries, Mumbai was used in the study for estimation of pentobarbitone sleeping time. It was given in the dose of $30 \mathrm{mg} / \mathrm{kg}$ i.p. ${ }^{14}$

5) The kits for all biochemical estimations were purchased from Transasia Diagnostic Pvt. Ltd. Mumbai. All chemicals used were of analytical grade.

\section{Study Design}

Animals were randomly divided into 5 groups of six animals each. All the animals, except D.W. control group-I, received $\mathrm{CCl}_{4}(0.5 \mathrm{ml} / \mathrm{kg} / \mathrm{d} \text { i.p. })^{10}$ for 7 days. The groups were treated as follows:

Group I: D.W. Control (0.5 ml/kg/d Distilled Water i.p.) for 7 days

Group II: Toxic/ $\mathrm{CCl}_{4}$ Control $(0.5 \mathrm{ml} / \mathrm{kg} / \mathrm{d}$ i.p. $)$ for 7 days Group II: $\mathrm{TMZ}_{1}\left(5 \mathrm{mg} / \mathrm{kg}\right.$ orally) from $1^{\text {st }}$ to $14^{\text {th }}$ day Group IV: $\mathrm{TMZ}_{2}(10 \mathrm{mg} / \mathrm{kg}$ orally $)$ from $1^{\text {st }}$ to $14^{\text {th }}$ day Group V: Liv $52^{\circledR}\left(1 \mathrm{ml} / \mathrm{kg}\right.$ orally) from $1^{\text {st }}$ to $14^{\text {th }}$ day

\section{Assessment of hepatic function}

On day 0 and day 15, all animals were weighed. Their functional status was ascertained using the parameter pentobarbitone sleeping time (PST). After giving single i.p. injection of pentobarbitone animal loses Righting Reflex. The interval between loss and regaining of Righting Reflex indicates sleeping time. Blood was collected from retro-orbital sinus under ether anaesthesia for testing biochemical markers [Liver Function TestsSerum Bilirubin, Serum Glutamic Pyruvic Transaminase (SGPT), Serum Glutamic Oxaloacetic Transaminase (SGOT), Serum Alkaline Phosphatase (SALP) and Serum Proteins. 
On $15^{\text {th }}$ day, after withdrawal of blood, all the animals were sacrificed by ether anaesthesia and liver were dissected out. Part of the liver was processed for histopathological studies.

The liver tissue sections were fixed in $10 \%$ buffered neutral formalin for 48 hours and processed according to standard histological techniques and stained with hematoxylin and eosin and examined microscopically under High Power (40X) for histopathological changes. The histopathological assessment of liver damage was done by scoring of structural changes described by National Health Services Meryland, USA. ${ }^{15}$

The parameters were as follow

a. Degeneration (0-No degeneration, 1-few vacuolated cells per lesion, 2-more than 10 vacuolated cells per lesion, 3- one to two rows of vacuolated cells around necrotic zone per lesion, 4- more than two rows of vacuolated cells around necrotic zone per lesion)

b. Necrosis (0-No necrosis, 1-Focal necrosis of one or two cells per lesion, 2-focal necrosis of more than two cells per lesion, 3-massive centrilobular necrosis, 4massive centrilobular necrosis with necrotic tissue bridging the central vein)

c. Fibrosis (0-normal appearance of liver, 1-central necrosis, hydropic degeneration, no fibrosis, 2- fibrous tissue in periportal area only, 3- Fibrous tissues insinuating surrounding hepatic parenchyma, 4formation of pseudolobules) d. Regeneration (0-no Regeneration, 1- Mild, 2Moderate, 3- Excellent)

\section{Statistics}

The results were presented as the mean \pm SEM. The Statistical package, Graph Pad Prism 5 was used to analyze all the results. Analysis of Variance (ANOVA) followed by post hoc analysis (Dunnett's test) was used for analysis of data and for comparisions between treated and control groups. The Paired Student's ' $t$ ' test was used to compare the data obtained at baseline (i.e. Day 0) and on Day 15, in all the groups. The level of significance was set at $\mathrm{P}<0.05$.

\section{RESULTS}

Baseline SGPT, SGOT and ALP were comparable in all the groups. Intergroup comparison of all observations on day 15 is presented in Table $1 . \mathrm{CCl}_{4}$ treated animals in toxic control group II produced significant $(\mathrm{p}<0.001)$ rise in SGPT, SGOT and ALP indicating hepatotoxicity caused by $\mathrm{CCl}_{4}$. Trimetazidine (TMZ), when given prophylactically, in low as well as high doses, could significant reduce the SGPT, SGOT $(\mathrm{p}<0.001)$ and ALP $(p<0.01)$ levels in animals of groups III and IV.

Liv. $52^{\circledR}$ administered prophylactically, also produced significant $(\mathrm{p}<0.001)$ reduction in SGPT, SGOT and ALP.

Table 1: Effects of TMZ and Liv. $52^{\circledR}$ on Liver enzymes in $\mathrm{CCl}_{4}$ induced hepatotoxicity in rats.

\begin{tabular}{|c|c|c|c|c|c|c|}
\hline \multirow[t]{2}{*}{ Groups } & \multicolumn{2}{|c|}{ SGPT (IU/L) } & \multicolumn{2}{|l|}{ SGOT (IU/L) } & \multicolumn{2}{|l|}{ S.ALP (IU/L) } \\
\hline & Day 0 & Day 15 & Day 0 & Day 15 & Day 0 & Day 15 \\
\hline I- D.W. Control & $54.66 \pm 2.33$ & $58.8 \pm 3.6$ & $149.17 \pm 7.66$ & $153.00 \pm 5.58$ & $228.67 \pm 11.65$ & $270.0 \pm 11.03$ \\
\hline II- $\mathrm{CCl}_{4}$ Control & $51.33 \pm 2.70$ & $181.5 \pm 6.44^{\#}$ & $150.00 \pm 4.06$ & $330.33 \pm 18.39^{\#}$ & $247.00 \pm 21.98$ & $368.83 \pm 17.62^{\#}$ \\
\hline IV- $\mathrm{CCl}_{4}+\mathrm{TMZ2}$ & $51.00 \pm 2.13$ & $131.16 \pm 3.81 * * *$ & $150.33 \pm 4.65$ & $246.83 \pm 6.95 * * *$ & $255.83 \pm 13.08$ & $308.83 \pm 12.49 * * *$ \\
\hline $\mathrm{V}-\mathrm{CCl}_{4}+\mathrm{Liv} .52^{\circledR}$ & $51.5 \pm 3.13$ & $114.16 \pm 4.20 * * *$ & $150.83 \pm 4.32$ & $207.50 \pm 6.24 * * *$ & $260.83 \pm 15.52$ & $302.00 \pm 14.73 * * *$ \\
\hline
\end{tabular}

Values indicate Mean \pm S.E.M. ${ }^{*}$ means $\mathrm{P}<0.001$ as compared to D.W. control group. $* \leq 0.05, * * \leq 0.01, * * * \leq 0.001$ in comparison with $\mathrm{CCl}_{4}$ control. TMZ- Trimetazidine, SGPT - Serum Glutamic Pyruvic Transaminase, SGOT - Serum Glutamic Oxaloacetic Transaminase, S.ALP - Serum Alkaline Phosphatase

As seen in Figure $1, \mathrm{CCl}_{4}$ control group showed significant reduction $(\mathrm{p}<0.001)$ in Total protein and Albumin levels as compared to DW control group. As compared to $\mathrm{CCl}_{4} /$ toxic control group, Liv52 ( $\left.<<0.001\right)$, $\mathrm{TMZ}_{2}(\mathrm{p}<0.01)$ and $\mathrm{TMZ}_{1}(\mathrm{p}<0.05)$ showed less reduction in Total protein and Albumin levels.

Figure 1 also showed significant increase $(p<0.001)$ by $\mathrm{CCl}_{4}$ in Total Bilirubin and Direct Bilirubin as compared to DW control group. As compared to $\mathrm{CCl}_{4} /$ toxic control group, Liv52 $(\mathrm{p}<0.001)$ and $\mathrm{TMZ}_{2}(\mathrm{p}<0.01)$ showed less rise in Total protein and Albumin levels.

Figure 2 showed almost similar pentobarbitone sleeping time (PST) in minutes in all groups on day 0. However, on day 15 , there was significant rise in PST $(\mathrm{p}<0.001)$ in $\mathrm{CCl}_{4}$ treated rats as compared to DW control group. PST with $\mathrm{TMZ}_{1}, \mathrm{TMZ}_{2}$ and Liv52 ${ }^{\circledR}$ treatment in the respective groups was significantly less $(\mathrm{p}<0.001)$ as compared to $\mathrm{CCl}_{4}$ control group. 


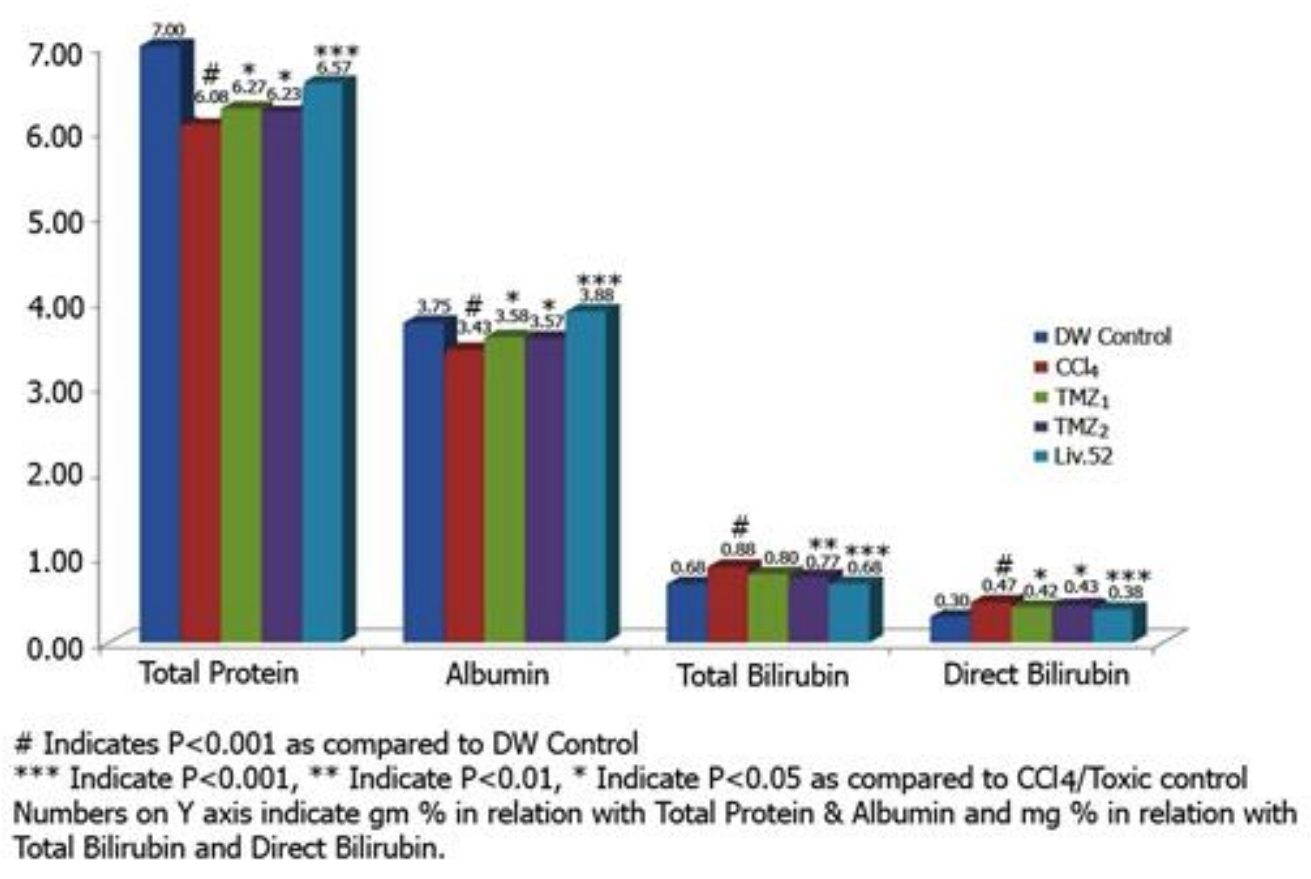

Figure 1: Effect of $\mathrm{TMZ}_{1}, \mathrm{TMZ}_{2}$ and Liv. $52^{\circledR}$ on S. Bilirubin and S. Proteins in $\mathrm{CCl}_{4}$ induced hepatotoxicity.

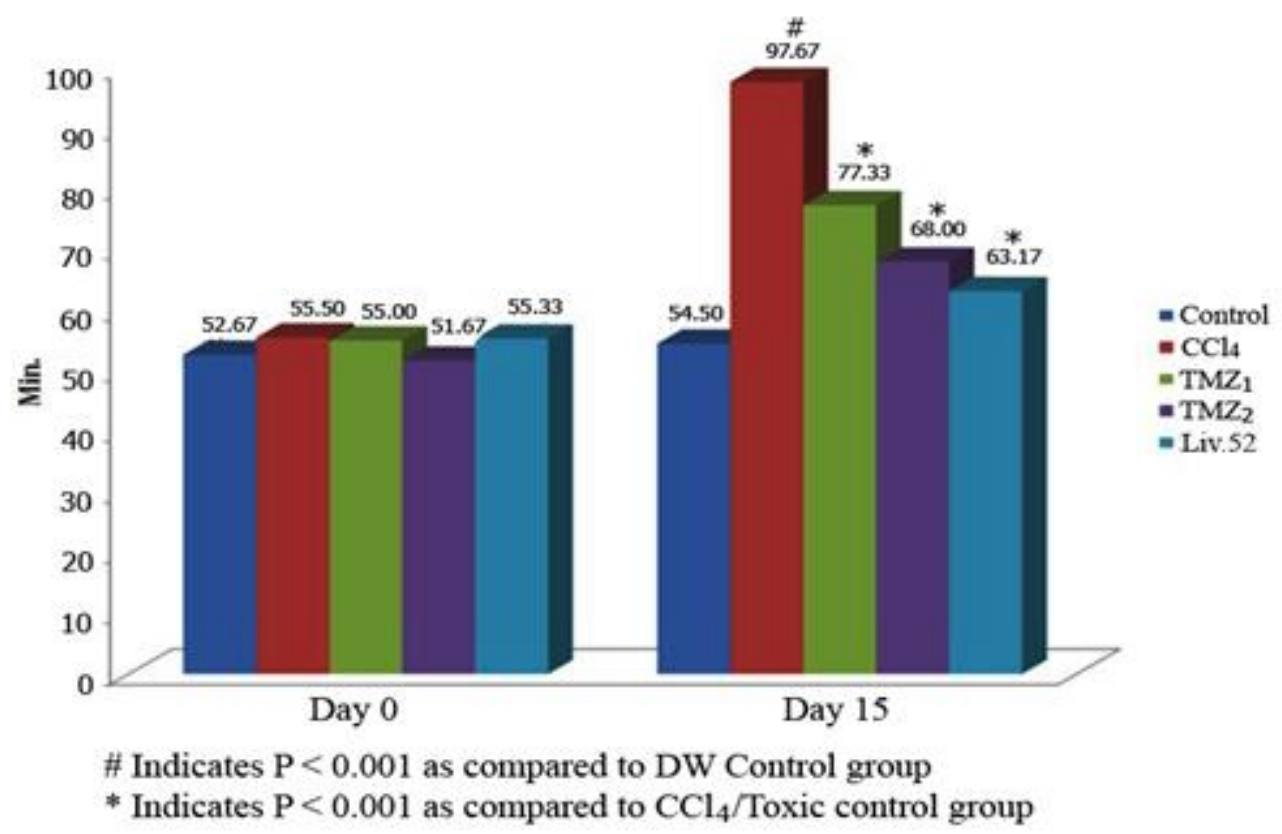

Figure 2: Comparison of pentobarbitone sleeping time in different groups on day 0 and day 15.

Table 2 summarizes the histopathological findings which showed normal hepatic architecture in the DW control rats, whereas that of $\mathrm{CCl}_{4}$-treated group showed significant Degenerative $(\mathrm{p}<0.001)$, Necrotic changes $(\mathrm{p}<0.05)$ and fibrotic changes. Such changes were also seen in all drug treated groups. Though $\mathrm{TMZ}_{1}$ and $\mathrm{TMZ}_{2}$ showed improvement in histopathological scoring as compared to $\mathrm{CCl}_{4}$-treated group, difference is not statistically significant. Liv $52^{\circledR}$ showed significant improvement $(\mathrm{p}<0.01)$ in level of degeneration. Only in $\mathrm{TMZ}_{2}$ and Liv52 groups, regenerative changes were seen. 
Table 2: Effects of $\mathrm{TMZ}_{1}, \mathrm{TMZ}_{2}$ and Liv $\mathbf{5 2}^{\circledR}$ on histopathological changes in $\mathrm{CCl}_{4}$ induced hepatotoxicity in rats.

\begin{tabular}{|c|c|c|c|c|}
\hline Groups & Degeneration & Necrosis & Fibrosis & Regeneration \\
\hline I-D.W. Control & 0 & 0 & 0 & 0 \\
\hline II- $\mathrm{CCl}_{4}$ Control & 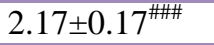 & $1.33 \pm 0.33^{\#}$ & $0.33 \pm 0.21$ & 0 \\
\hline III- $\mathrm{CCl}_{4}+\mathrm{TMZ1}$ & $1.67 \pm 0.21$ & $1.17 \pm 0.17$ & $0.33 \pm 0.21$ & 0 \\
\hline IV- $\mathrm{CCl}_{4}+\mathrm{TMZ} 2$ & $1.5 \pm 0.22$ & $1.00 \pm 0$ & $0.17 \pm 0.17$ & $0.17 \pm 0.17$ \\
\hline $\mathrm{V}-\mathrm{CCl}_{4}+\mathrm{Liv} .52^{\circledR}$ & $1.17 \pm 0.17^{* *}$ & $0.67 \pm 0.21$ & $0.17 \pm 0.17$ & $0.17 \pm 0.17$ \\
\hline
\end{tabular}

Values indicate Mean \pm S.E.M. ${ }^{\#}$ means $\mathrm{P}<0.05,{ }^{\# \#}$ means $\mathrm{p}<0.001$ as compared to normal control group. $* *<0.01$ in comparison with $\mathrm{CCl}_{4}$ /toxic control.

\section{DISCUSSION}

Exposure to toxins is prevalent in present era of industrialization and the entry of chemicals into the body can produce many deleterious effects in human beings. In an effort to protect the body from deleterious effects, liver is one of the important organs which get severely damaged as a result of chronic exposure to toxins. Toxin may be in the form of a drug, a pesticide, an industrial effluent or any other chemical entity. Viral hepatitis is yet another common disease in the world, especially in the developing countries affecting liver. However, there are very few effective drugs for the treatment of most of the hepatic ailments. Thus, there is need to develop potent hepatoprotective agents against such hepatic dysfunctions. In recent years, considerable amount of research has been carried out in this regard.

Till date, there are very few drugs which have been conclusively shown to be effective in prevention and treatment of liver damage. Both natural and synthetic substances have been evaluated as hepatoprotective agents like Tinospora cordifolia, ${ }^{16}$ Picrorrhiza kurroa $^{17}$ etc. However, they are dispensed as a mixture of crude extract, their mechanisms are not fully known and their place in therapy is not definitely established. Some drugs in Modern medicine have shown encouraging hepatoprotective results in experimental animals like melatonin, ${ }^{18}$ adenosine ${ }^{19}$ etc.

Liver injury can be produced by many mechanisms like formation of reactive metabolite, immunological injury and others. Since the changes associated with $\mathrm{CCl}_{4}$ induced liver damage are similar to that of acute viral hepatitis and drug induced liver damage; $\mathrm{CCl}_{4}$ mediated hepatotoxicity is commonly employed as the experimental model for liver injury. This toxic chemical causes peroxidative degradation in the adipose tissue, resulting in fatty infiltration of the hepatocytes. Its metabolites such as trichloromethyl radical $\left(\mathrm{CCl}_{3}\right)$ and trichloromethyl peroxy radical $\left(\mathrm{CCl}_{3} \mathrm{O}_{2}\right)$ are involved in the pathogenesis of liver damage. $\mathrm{CCl}_{4}$ causes change around the central vein in the liver and other oxidative damages with the leakage of marker enzymes like SGOT, SGPT and ALP in the serum and decrease in serum total protein. ${ }^{20,21}$
The present work was aimed at evaluating the hepatoprotective effect of the antianginal drug trimetazidine against Carbon Tetrachloride induced liver damage in rats. The prophylactic administration of two doses (low and high) of trimetazidine was studied.

Acute toxic injury to the liver induces widespread necrosis followed by rapid regeneration. If necrotizing effect of $\mathrm{CCl}_{4}$ is extensive and could not match the regeneration, the animal dies. But if lesser amounts are used, even on repeated dosing i.e. in subacute dosing, regeneration compensates diffuse necrosis and the animal survives. After repeated administration of $\mathrm{CCl}_{4}$ for few weeks, gradual development of cirrhosis occurs. Early liver damage can be reverted towards normal by using certain hepatoprotective agents. In our experiment, we were interested to evaluate reversal of early hepatic damage (Steatosis) caused by $\mathrm{CCl}_{4}$.

TMZ shifts energy metabolism from fatty acid oxidation to glucose oxidation by inhibiting mitochondrial long chain 3-ketoacyl CoA thiolase. ${ }^{22}$ Reduced fatty acid oxidation results in reduced Acetyl CoA formation which is required for biosynthesis of fats. Thus, TMZ prevents accumulation of fat. It is also shown to have antioxidant activity $^{23}$. In this way, it may prevent processes of Steatosis and Steatohepatitis respectively (Figure 3). So, effort was made to evaluate hepatoprotective activity of TMZ.

Hepatic damage was studied using following parameterspentobarbitone sleeping time, Biochemical markers and histopathological changes.

Functional status of liver was assessed by measuring metabolic capacity of the liver. Pentobarbitone is extensively metabolized in the liver. When liver is damaged, pentobarbitone metabolism is reduced and its effect measured as pentobarbitone Sleeping Time (PST) ${ }^{24}$ It was observed from our study that $\mathrm{CCl}_{4}$ had increased PST significantly $(\mathrm{p}<0.001) \quad$ indicating derangement in functional status of liver. Significantly $(\mathrm{p}<0.001)$ less reduction in PST was observed with $\mathrm{TMZ}_{1}, \mathrm{TMZ}_{2}$ and Liv52 ${ }^{\circledR}$ (Figure 2). 


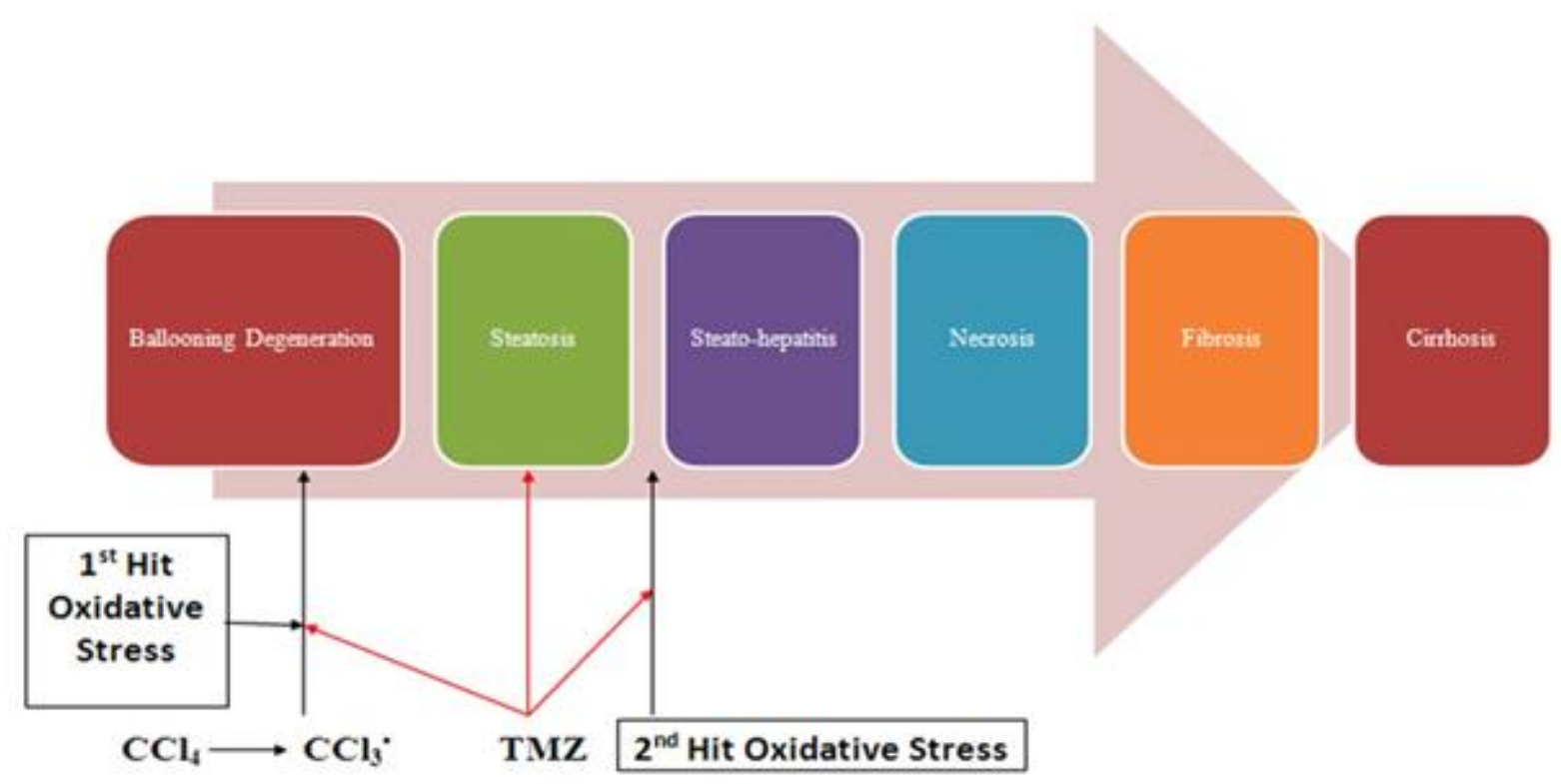

Figure 3: Steps of trimetazidine action.

Hepatic damage was also assessed biochemically by performing Liver Function Tests. Rise in SGPT and SGOT was indicative of hepatocellular damage and rise in Serum Alkaline Phosphatase indicates obstructive liver disease. ${ }^{25}$ Highly significant increase in the levels of all the liver enzymes were seen with $\mathrm{CCl}_{4}$ treated rats (Table no.1). Our results were similar to those seen by Sisodia SS et al. ${ }^{26}$ It also showed significantly less rise in all biochemical markers after administration of TMZ (low and high dose) and Liv. $52^{\circledR}$ indicating hepatoprotective effect of Trimetazidine.

Histopathological scoring was done on the basis of Degeneration (0-4), Necrosis (0-4), Fibrosis (0-4) and Regeneration (0-3). Histopathological damage produced by $\mathrm{CCl}_{4}$ was highly significant. Significant reduction in histopathological scores of fibrosis $(p<0.01)$ was observed with Liv.52 ${ }^{\circledR}$ (Table no.2) when given prophylactically as compared with $\mathrm{CCl}_{4}$ treated rats. Though scores in all the remaining treatment groups $\left(\mathrm{TMZ}_{1}\right.$ and $\left.\mathrm{TMZ}_{2}\right)$ were less in comparison to that in $\mathrm{CCl}_{4}$ treated group, the difference was not statistically significant. $\mathrm{TMZ}_{2}$ and liv52 showed changes of regeneration.

Studies have shown that administration of Liv. $52^{\circledR}$, a polyherbal formulation, significantly improved ethanol metabolism in a rat model of chronic alcohol administration. ${ }^{27}$ It also has shown to prevent lipid peroxidation in $\mathrm{CCl}_{4}$ induced liver damage by significant decrease in malondialdehyde content. $^{28}$ So we used Liv. $52^{\circledR}$ as positive control which prevented the rise in the enzyme levels after $\mathrm{CCl}_{4}$ treatment. Our study also showed the hepatoprotective effect of Liv. $52^{\circledR}$ in the $\mathrm{CCl}_{4}$ treated rats with a significant reduction of PST, liver enzymes as well as histopathological changes.
Thus our study showed $\mathrm{CCl}_{4}$ induces significant hepatic damage as observed by derangement of functional status of liver, liver function tests and histopathology of liver. Trimetazidine in both the doses, $\mathrm{TMZ}_{1}$ and $\mathrm{TMZ}_{2}$, showed marked improvement in these markers of liver damage which is comparable with our positive control $\operatorname{Liv} 52^{\circledR}$.

\section{CONCLUSION}

There is definite improvement in functional status of liver, biochemical markers and histopathological scores by TMZ, in both the doses which is comparable with Liv52 ${ }^{\circledR}$. Thus we can conclude that trimetazidine, especially in the dose of $10 \mathrm{mg} / \mathrm{kg}$, has hepatoprotective activity against $\mathrm{CCl}_{4}$ induced liver damage in rats when administered prophylactically.

Funding: No funding sources Conflict of interest: None declared

Ethical approval: The study was approved by the Institutional Animal Ethics Committee (Approval Letter No. IAEC /BVDUMC/07/2009-2010 dated 2/9/2009)

\section{REFERENCES}

1. Sheila Sherlock, James Dooley. Drug and the liver. In: Diseases of the liver and biliary system. $11^{\text {th }}$ edition. Paris: Blackwell Publishing; 2002: 335.

2. Christine K, Cassel. Geriatric medicine: an evidencebased approach. $4^{\text {th }}$ edition. New York: Springer publication; 2003: 844 .

3. Anthony S. Fauci, Eugene Braunwald, Dennis Kasper, Tinsley Randolph Harrison, Dan L. Longo. Harrison's principles of internal medicine. $17^{\text {th }}$ edition. New York: McGraw-Hill Medical Publication; 2008: 264-8. 
4. Manouchehr Khoshbaten, Akbar Aliasgarzadeh, et al. N-Acetylcysteine Improves Liver Function in Patients with Non-Alcoholic Fatty Liver Disease. Hepatitis Monthly. 2010;10(1):12-16.

5. Charles S Lieber. $S$-Adenosyl-L-methionine: its role in the treatment of liverdisorders. Am J Clin Nutr. 2002;76(suppl):1183S-7S.

6. Parola M, Leonarduzzi $\mathrm{G}$ et al. Vitamin E dietary supplementation protects against carbon tetrachloride-induced chronic liver damage and cirrhosis. Hepatology. 1992Oct;16(4):1014-21.

7. Sean C. Sweatman, Editor. Martindale: The Complete Drug Reference. $34^{\text {th }}$ edition. London: Pharmaceutical Press; 2005: 1018.

8. Tripathi KD. Essentials of Medical pharmacology. $6^{\text {th }}$ edition. New Delhi: Jaypee publication; 2008: 535.

9. Ghosh MN. Fundamentals of Experimental Pharmacology. $4^{\text {th }}$ edition. Hilton and company; 2008: 178-179.

10. Maheshwari M. Uma, Rao PGM. Antihepatotoxic effect of grape seed oil in rat. Indian journal of Pharmacology. 2005June;37(3);179-82.

11. Kolhapure, S.A., Mitra, S.K. Meta-analysis of 50 Phase III clinical trials in evaluation of efficacy and safety of Liv.52 in infective hepatitis. Medicine Update. 2004;12(2)51-61.

12. Shivani Pandey, Gujrati VR, Shanker K, Singh N and Dhawan KN. Hepatoprotective effect of Liv. $52^{\circledR}$ Against CCl4-induced Lipid Peroxidation in Liver of Rats. Indian Journal of Experimental Biology. 1994September;32:674-5.

13. Sisodia SS, Bhatnagar M. Hepatoprotective activity of Eugenia jambolana Lam.in carbon tetrachloride treated rats. Indian journal of Pharmacology. 2009Feb;41(1):23-7.

14. Ahmad Ghorbani, Hassan Rakhshandeh et al. Potentiating Effects of Lactuca sativa on Pentobarbital-Induced Sleep. Iranian Journal of Pharmaceutical Research. 2013;12(2):401-6.

15. Davidson C.S. - Guidelines for detection of hepatotoxicty due to drugs and chemical. USA: NIH publication, U.S. Department of Health and Education and Welfare NIH. 1979.

16. Koul IB, Kapil A. Effect of diterpenes from andrographispaniculata on antioxidant defense system and lipid peroxidation. Indian Journal of Pharmacology. 1994;26;296 - 300.

17. Rastogi R, Saksena S, Garg NK, Kapoor NK, Agarwal DP, Dhawan BN. Picroliv protects against alcohol-induced chronic hepatotoxicity in rats; PlantaMedica Journal. 1996June;62(3):283-5.

18. Stanca MH, Nagy A, Toaya M, Vlad L. Hepatoprotective effects of orally administered melatonin and tinosporacordifolia in experimental jaundice. Chirurgia (Bucur). 2011MarApr;106(2):205-10.

19. Chagoya de Sajnchez V, Hernajndez-Muaoz R, Yajaez L, Vidrio S, Da-az-Muaoz M. Possible mechanism of adenosine protection in carbon tetrachloride acute hepatotoxicity. Role of adenosine by-products and glutathione peroxidase. Journal of Biochemical Toxicology. 1995Feb;10(1):41-50.

20. Recnagel RO. Carbon tetrachloride hepatotoxicity status and future prospects.Pharmacol Sci 1983;4:129-31.23.

21. Okuno H, Hazama H, Muraze T, Shiozaki Y, Sameshima Y. Drug metabolizing activity in rats with chronic liver injury induced by carbon tetrachloride: Relationship with the content of hydroxyproline in the liver. Jpn $\mathbf{J}$ Pharmacol 1986;41:363-71.

22. Paul F. Kantor, Arnaud Lucien, Raymond Kozak, Gary D. Lopaschuk. The Antianginal Drug Trimetazidine Shifts Cardiac Energy Metabolism From Fatty Acid Oxidation to Glucose Oxidation by Inhibiting Mitochondrial Long-Chain 3-Ketoacyl Coenzyme A Thiolase. Circulation Research Journal. 2000;86:580-8

23. Ferhan Girgin, Onderkaraoglu, Muhan Erkus, Sevgi Tuzun. Effects of Trimetazidine on oxidant/antioxidant status in trinitrobenzenesulfonic acid induced chronic colitis. Journal of toxicology and environmental health,part A. 2000;59(8):641-52.

24. Michael T. Piel, J. Antonio Aldrete and George Jones. Influence of enzyme induction on the sleeping time of rats. Canadian Journal of Anesthesia. 1969Nov;16(6): 538-46.

25. Shah Shantilal J. editor, Antia FP, Naik SR. Liver Function Tests.In:A.P.I. text book of medicine. $4^{\text {th }}$ edition. Bombay: Association of physicians of India; 1988: 633-4.

26. Sisodia SS, Bhatnagar M. Hepatoprotective activity of Eugenia Jambolana Lam. In carbon tetrachloride treated rats. Indian journal of Pharmacology. 2009Feb;41(1):23-7.

27. Chauhan BL, Mohan AR, Kulkarni Rd, Mitra SK. Bioassay for evaluation of the hepatoprotective effect of liv. $52^{\circledR}$, a polyherbal formulation, on ethanol metabolism in chronic alcohol - exposed rats. Indian Journal of Pharmacology. 1994;26: 117 - 20.

28. Shivani Pandey, Gujrati VR, Shanker K, Singh N and Dhawan KN. Hepatoprotective effect of Liv. $52^{\circledR}$ Against CCl4-induced Lipid Peroxidation in Liver of Rats. Indian Journal of Experimental Biology. 1994 Sep;32:674-5.

doi:10.5455/2319-2003.ijbcp20140221

Cite this article as: Mate VH, Pandit VA, Wani DB, Dhande PP. Role of trimetazidine in carbon tetrachloride induced liver damage in rats. Int J Basic Clin Pharmacol 2014;3:164-70. 